\title{
A.JO'ГE
}

Africa Journal of Teacher Education

ISSN 1916-7822. A Journal of Spread Corporation

$\begin{array}{llll}\text { Vol. } 6 & \text { No.1 } 2017 \quad \text { Pages 22-38 }\end{array}$

\section{The Utilization of Social Media in the Classroom by Business Teacher Educators in Nigeria}

\author{
Dr. James L. Morrison \\ University of Delaware, US \\ Dr. John Oyedele \\ Kwara State University, Nigeria \\ Professor G. T. Oladunjoye \\ Kwara State University, Nigeria \\ Mr. Joshua Maman \\ Kwara State University, Nigeria
}

\begin{abstract}
The objective of the study was to determine how frequently social media is being utilized by business teacher educators in Nigeria and for what purpose. Specifically, the research problem was to determine the kinds of pedagogical practices associated with using social media for teaching. Surveys were received from 69 business teacher educators situated in 5 states in Nigeria of which 41 were from polytechnic institutions, 22 from colleges of education, and 5 from universities. The findings indicate that social media is only being marginally implemented in business teacher education in Nigeria. However, a significant number of business teacher educators would like to see the use of social media expanded by becoming more informed as to instructional alternatives.
\end{abstract}

\section{Introduction}

There are approximately 200 social media platforms (Wikipeda) being utilized around the world. The five most often used are Facebook, Youtube, Google+, and Twitter. In Nigeria, 28.4\% or 48.4 million citizens are active social media users with $45 \%$ of these being students under age 18 (Ejechi \& Nelson, 2014.) The youth in Nigeria are very aware of social media and its capacity to enable 
them to connect with one another during their daily lives. Of the 82 colleges of education in Nigeria, 21 are classified as Federal, 41 State, and 20 Private Institutions. There are also 81 polytechnic institutions where business teachers are also prepared. The use of social media in education in Nigeria is primarily reflected in the use of Facebook, and Twitter etc. (Ejechi, \& Nelson, 2014). A primary issue investigated in this study was whether school managers, especially of post-secondary institutions, are currently providing the leadership required to bring their programs in line with the social media capabilities of students arriving to their institutions, and in this case, for business teacher preparatory programs.

Business Teacher Preparatory programs in Nigeria are part of a national effort to provide vocational education throughout the country. The availability of social media as an instructional enhancement provides an intriguing alternative for business teachers to advance new approaches for teacher training. Social media has been defined in different ways. For this study, we use the definition advanced by Bryer and Zavatarro (2011, p. 327): "Social media are technologies that facilitate social interaction, make possible collaboration, and enable deliberation across stakeholders. These technologies include blogs, wikis, media (audio, photo, video, text) sharing tools, networking platforms (including Facebook), and virtual worlds." Successful adaptation of social media as an instructional aid also depends on the skill levels of business teachers who would use them. This study provides an insight into the extent of social media use in the learning process by business teacher educators across Nigeria. The findings of the study will be useful in determining the desire, both current and in the future, of business teacher educators to address issues related to utilizing social media for meeting the educational needs of those undergraduates preparing to become business teachers.

\section{Literature Review}

Social media use is gaining traction, especially in educational institutions around the world. Social media consists of a variety of Internet-based applications built on the technology associated with Web 2.0, which enables the creation and exchange of client produced content (Kaplan \& Haenlein 2010). Social media facilitates interaction among users through the creation and sharing of information via virtual communities. Social media is known to play an important role in collaboration, community building, and partnering. An intriguing aspect to social media is its use of mobile and online technologies (Jan \& Hermkens 2011). This technology exists in a variety of 
formats such as online forums, social-blogs, wikis, podcasts, and social networks (Mazer, Murphy, \& Simonds, 2007). Correspondingly, web-based technologies today support the social architecture of an educational community that enables students to become more fully engaged in the learning process (Suter, Alexander \& Kaplan, 2005).

\section{Direct Impacts of Social Media Upon the Educational Process.}

As educators search for approaches to connect with and motivate students, they are discovering that social media platforms are turning into an intriguing alternative to the conventional learning environment (Ebner, Lienhardt, Rohs, \& Meyer, 2010). A search of the literature in social media use in educational programs in the US, Turkey, and India, among other nations, indicates that social media is redefining relationships between students and their teachers (Miller, et.al.,2016). Its use has resulted in creating collaborative opportunities to discover and share information (Solis, 2008). In this regard, Sherer and Shea (2011) suggest that social media can be an instructional alternative to get across a teacher's ideas from the very start of classes. It is also a strategy for tracking learning outcomes online. The social media's most distinctive aspect is its potential to transform from pushing content outward to engaging in conversation for actually exchanging information. Such platforms as Facebook, Twitter, Myspace, LinkedIn, SlideShare, and Flickr are examples of tools available to business teacher trainers for use in the classroom. Blogs, wikis, online videos and podcasts are other forms of connecting to students as they learn how to become effective business teachers in the future (Sherer, \& Shea, 2011).

A study conducted by Osharive Peter (2015) at the University of Lagos, using a random sample of 378 students selected from 24,661 full-time undergraduate students, found that undergraduate students are very much familiar with the use of social media. Peter (2015) also found that there is a positive relationship between academic success and use of social media. He thus recommended that utilizing social media in education is helpful for enhancing academic activities, but he also cautioned that students should be monitored by teachers on how they use these sites. Social networking media included as examples for adoption were Twitter, Yahoo Messenger, WhatsApp, Facebook Messenger, Blackberry Messenger (BBM), 2go messenger, Skype, Google talk, Google Messenger, among others.

A study by Umoru (2015) of Kwara State University, Nigeria, revealed that appropriate use of social media for instructional purposes reinforces the role of teachers in Nigeria universities to 
better prepare graduates for a global workforce. He argues that the use of social media will enhance the exchange of 'user generated content' for bringing the classroom experience in line with workplace realities. To Umoru (2015), the need to prepare business education students to fit into the world of work in the 21st century (and combat high unemployment in Nigeria) is the major reason that social media skills must be acquired by them.

\section{Applying Connectivism Theory to Learning.}

In the new digital age, Siemens (2004; 2005) and Downes (2007) proposed the 'connectivism theory,' where social learning is integrated with social media technologies. In the world of social media proliferation, learning is not an internal, individualistic activity. Rather, learners gather information from connecting to the knowledge of others using Wikipedia, Twitter, RSS (Rich Site Summary), and other similar platforms. One of the principles of 'connectivism' is that the capacity to learn is more critical than simply accumulating knowledge (Siemens, 2004). The responsibility of a teacher is not just to produce content, but to help students build learning paths and make connections between existing and new knowledge (Anderson \& Dron, 2011). The theory of 'connectivism' enables business teacher educators to gain insight on how to design-a more inclusive learning environment. On a daily basis they use desktop computers, laptops, e-readers, tablets, and cell phones to actively engage in social networking, text messaging, blogging, content sharing, online learning, and much more (Cassidy, Griffin, Manolovitz, Shen, \& Turney, 2011). In this regard, the theory of 'connectivism' is being considered by some teacher educators as a useful approach to learning, a perspective that is addressed in this study in the country of Nigeria.

\section{Social Media Currently Utilized by Students.}

Liu (2010) studied a sample of American students' use of different social media tools and their attitudes and perceptions towards these tools. Liu sought to identify the knowledge and trends of using 16 social media tools that included Facebook, Wiki, YouTube, Bulletin Board, LinkedIn, Blogs, Twitter, Podcasts, Virtual Worlds, RSS, StumbleUpon, Netlog, Delicious, Digg, Plurk, and Jaiku. As part of the study, 221 students were asked to rate their knowledge of each social media tool. Study results revealed that about $70 \%$ of the students in the sample were either "very knowledgeable" or "knowledgeable" about YouTube, Wiki, and Facebook. In addition, about 40\% were "somewhat knowledgeable" about podcasts, blogs, and forums. Finally, only 25\% were "not at all knowledgeable" about using Twitter. The study results also revealed the top four reasons 
why students use social media tools were for general social engagement (85\%), for direct communication to close friends and family (58\%), for speed of feedback/results (48\%), and for relationship building (47\%) However, fewer than $10 \%$ of the students used social media tools as part of their academic program. In a similar study, Browning, Gerlich, and Westermann (2011) surveyed 141 undergraduate students regarding their perceptions of social media. The data revealed that there were favorable perceptions of social media as well as a high degree of readiness to embrace social media portals to have course content delivered to them.

\section{Social Media Currently Utilized by Business Teacher Educators.}

Research on the use of social media in teaching by business teacher educators in countries around the world, and specifically in Nigeria, is quite limited. Although outside the field of business teacher education, one notable study of interest regarding use of social media in general in education is the Survey of Student Engagement (FSSE, 2010). In this study, 4,600 faculty members from 50 U.S. colleges and universities were surveyed. The outcomes of the study indicated that over $80 \%$ of the faculty surveyed never used social media technologies in the classroom. Unfortunately, that study did not disaggregate data for business education faculty; hence, we lack empirical research identifying to what degree social media is currently being integrated into their teaching. However, there is considerable research supporting 'connectivism theory' that connects the benefits in using social media to success in learning (Mazer, et. al., 2007). This research showed that students generally attribute higher levels of instructor credibility and learning to those faculty who willingly self-disclose or distribute information through social media than those who did not. Mills (2011) also draws attention to the value of social-networking tools for their capacity to attract, motivate and engage faculty in meaningful interactive teaching practices, content exchange, and collaboration. Some attributes that Mills associates with social networking as an instructional tool in education include:

1. Flexibility. To Mills (2011), face-to face classes can be somewhat inhibiting for some to learn effectively, while the convenience and flexibility of online components can motivate students to complete educational tasks. Expanding the choice on what, when, where and how people learn supports different styles of learning. Utilizing instructional forums, such as chat rooms that exist in social networking, provide opportunities for 
faculty and students to exchange views on topics without intimidation or direct fear of rejection (see also, Cheong, et.al., 2005).

2. Repetitive Capacity to Recall What has been Learned. Research findings indicate that repetition is rarely featured in traditional educational methods (Dobrzañski, Brom \& Brytan, 2007). However, the capacity of social networking enables faculty and students to revisit past learning on a systematic basis, thus providing a strategy for learners to retrieve information in a timelier fashion. To these researchers, repetition of thought enables information to become embedded in the learning centers within the brain. Thus, it can provide for a stronger understanding of what is being taught as well as an increased degree of retention by enabling students to recall past information at a moment's notice.

3. Accessibility. The social networking is easy and quick in term of accessing, reviewing, updating, and editing learning material anytime and anywhere (Cheong, et.al., 2005). It allows students to select learning materials from a large quantity of courses offered online. Social networking allows students to access courses for learning at any time, permitting the learner to overcome the limitations of space and time in the educational process. Also, access to information from sources around the world the knowledgebase for learning. Videos, scholarly articles, learning forums, and global exchange networks become accessible as a low-cost alternative for gathering data.

In summary, the research suggests that as social media is becoming increasingly ubiquitous to millennials, and educators are correspondingly beginning to recognize the potential benefits of using these tools for academic purposes (Hughes, 2009; Nellison, 2007). Uses of social media as learning tools are also being perceived more as connecting informal learning to the formal learning strategies. For instance, third-party social media tools, such as WordPress, Wikipedia, and LinkedIn, can include members outside the class and beyond the one-semester time duration at typical universities as well as connect learners with learning communities, experts in the field, and peers across the world.

\section{Research Methodology}

This study attempts to determine the degree to which pedagogical practices associated with using social media for teaching and learning are currently being utilized by business teacher educators 
in schools situated in Nigeria. The focus of the study is upon finding answers to three research questions

- RQ I: How frequently is social media utilized by business teacher educators in Nigeria?

- RQ II: For what purposes are social media utilized in teacher training?

- RQ III: What concerns do business teacher educators have regarding the use of social media for teaching?

Significance of the Research Area.

Business teacher preparatory programs in Nigeria are very important component to delivering effective educational vocational programs to residents of the country. However, business teacher preparatory programs in Nigeria have been suffering somewhat over the past decade due to reduced funding, resulting in lower student enrollment and thus fewer teachers being trained.

\section{Study Sample.}

Participants in the study were from 5 states of Nigeria. The sample included 90 business teacher educators, of which 10 were situated in a university, 30 in a college of education, and 50 in polytechnic institutions. The nomenclature for each classification of educational institution used in this study is that provided by the Ministry of Education in Nigeria.

\section{Data Collection Methodology.}

Given that there is relatively little data on pedagogies related to using social media in classrooms in Nigeria, we used a written survey that was administered by department chairs in each institution to gather our data. The survey instrument that we drew on was part of a pilot study consisting of 15 business teachers in preparatory programs at the university level. The trial run based on the pilot study indicated to us, when designing the survey, that our data gathering instrument had content validity. The survey instrument gathered data on the types of social media being utilized for both personal as well as professional purposes, the frequency of their use, the kinds of interactive instructional strategies being used, and the concerns of faculty relating to the impact of their use on learning. Also, the questionnaire included questions relating to what direction the use of social media is likely to take in both the short-term and long-term in Nigeria. Data were collected between January and February of 2016. 


\section{Data Analys is.}

All responses to the written survey were recorded in Excel spreadsheet. IBM SPSS statistical software package was utilized for developing frequency tables. Of the 90 surveys distributed to business teacher educators, 50 were situated in polytechnic institutions; 30, colleges of education; and 10, universities offering teacher preparatory programs in Nigeria. A total of 69 surveys were returned, representing an overall return rate of $76 \%$. Of those 69 survey instruments returned, 41 (or 60\% rate of return) were received from business teacher's educators in polytechnic institutions; 22 (or $31 \%$ rate of return), from colleges of education; and 5 (or $6 \%$ rate of return), from universities.

\section{Demographics of the Sample.}

Of the 69 surveys returned, 47 were responses from full-time faculty; 2 from part-time lecturers; 3 from adjunct lecturers, and 9 from heads of educational business teacher preparatory programs. (Eight respondents did not indicate their titles.) In terms of academic ranking, 23 were classified as instructor; 4, an assistant professor; 2 an associate professor and 1, a professor. In addition, 34 indicated other nomenclature in regard to title of position currently held in a business teacher preparatory program in Nigeria. (Five respondents did not indicate their rank.) In terms of access and use of the Internet, $40 \%$ of the sample indicated that they spend less than 5 hours per week on the Internet. Another 32\% indicated that they spend between 6 to 10 hours per week on the Internet. Finally, $28 \%$ spent on the average each week over 11 hours per week. Finally, in terms of teaching experience, 13 had been business teacher educators for less than 5 years; 14, between 6 and 10 years, and 39 over 11 years of experience. Two respondents did not indicate length of service on their survey forms.

\section{Frequency of Use of Social Media in the Classroom.}

As indicated in Table 1, business teacher educators in Nigeria in the study sample appear to incorporate the use of social media into their personal lives more frequently than into their instructional methodology when interacting with their students. Of the 69 business teacher educators responding to the survey, $56.5 \%$ or 39 teacher educators indicated that they used social media in their personal lives very often while only $33 \%$ or 23 of those in the sample indicated the same degree of use as part of their instructional methodology. 39 or $56.5 \%$ of these teacher educators integrate the use of social media into their classroom activities. 
Table 1. Frequency of Overall Use of Social Media Applications* by Business Teachers Educators $\quad(\mathrm{N}=69)$

\begin{tabular}{|c|c|c|c|c|}
\hline \multicolumn{3}{|c|}{$\frac{\text { Used as Part of }}{\underline{\text { Instruction }}}$} & \multicolumn{2}{|c|}{$\underline{\text { Personal Use }}$} \\
\hline & No. & $\%$ & No. & $\%$ \\
\hline Very Often** & 23 & 33.3 & 39 & 56.5 \\
\hline Occasionally & 7 & 10.2 & 18 & 26.1 \\
\hline Never & $\underline{39}$ & 56.5 & $\underline{12}$ & 17.4 \\
\hline Total & 69 & 100.0 & $\overline{69}$ & 100.0 \\
\hline
\end{tabular}

*Note: Social media - Facebook, Google, Linkedin Twitter YouTube, etc.

**Note: Very Often $=$ Almost Every Class or at least 3 times per week for Personal Use

Of the 39 business teacher educators who indicated they never used any forms of social media in the classroom, the most frequent reason indicated was fear of abuse when used by their students. (Table 2). The two reasons that ranked next in importance were the lack of social media experience and of technical support.

Table 2. Reasons to Not to Incorporate Use of Social Media in Instruction

\begin{tabular}{lc}
\multicolumn{1}{c}{$(\mathrm{N}=39)$} & No. \\
\hline Reason & 7 \\
Fear of abuse when used by students & 5 \\
Lack social media expertise & $\underline{5}$ \\
Unit lacks technical support to use it effectively & 4 \\
Too much work to monitor & 1 \\
Students post negative comments about you & $\underline{1}$ \\
Not worth bothering with & $\underline{16}$ \\
Missing data (no responses) & 39 \\
\hline
\end{tabular}


Degree of Use of Social Media as Part of Instructional Methodology.

When asked how interested they were in integrating social media into the classes, the majority of those 30 business teacher educators in the sample who currently incorporate it into their instructional methodology indicated a great deal of interest. Responses on exploring ways to integrate social media into the classroom via instructional activities revealed 21 or $70 \%$ of these business teachers showing great interest in having their students identify creative applications for integrating a variety of social media tools when teaching problem-solving. 20 or $66 \%$ had a similar interest in having their students integrate social media tasks into their lesson plans (Table 3). Responses on specific social media being used as part of classroom instruction revealed only 9 or $30 \%$ of the business teachers indicating they used Facebook; 8 or 27\%, YouTube; 6 or 20\%, Tweet posts; and 3 or $10 \%$, blogs. However, 19 or $63 \%$ of the business teacher educators did have their students discuss the ethical use of social media, along with 16 or $53 \%$ of them teaching individual responsibility not to abuse the process.

Table 3. Degree Social Media Integrated into Instructional Methodology $\quad(\mathrm{N}=30)$

Instructional Activity
Somewhat

A Great Deal

Specific Competencies Initiated -

No. $\% \quad$ No. $\%$

Use Facebook for students to share ideas

$9 \quad 30$

$14 \quad 46$

Use Youtube, etc., for students to view teaching strategies 8

Tweet/post status updates to students

Write Blogs About Teaching Topics

$\begin{array}{ll}5 & 17 \\ 3 & 10\end{array}$

$8 \quad 27$

$6 \quad 20$

$3 \quad 10 \quad 3 \quad 10$

Social Media Exploration -

Have students identify creative applications

for social media when problem-solving

Have student integrate social media when designing lesson plans

Teach ethical uses of social media

$5 \quad 17$

$21 \quad 70$

Have students explore ways to integrate social media

into their teaching strategies

Promote responsible use of social media

$4 \quad 13$

$9 \quad 30$

$6 \quad 20$

$8 \quad 27$
$20 \quad 66$

$19 \quad 63$

$19 \quad 63$

$16 \quad 53$


Administrative Interest in having Teacher Educators Integrate Social Media into their Classes. As depicted in Table 4 below, in terms of administrative interest in getting faculty to integrate social media into their instructional methodology systematically, 48 of the 69 business teacher educators in the sample indicated that there is not much interest on the part of their unit leadership or chair for promoting the use of social media in the classroom. Similarly, between 42 to 59 business teacher educators perceive their units as not having specific goals, policies, or assessment procedures in place for guiding business teacher educators with their social media utilization. The findings reveal that generally, most department chairs, 48 in number and well over $60 \%$, are not actively leading their units in having social media become an integral part of instructional methodology used by their faculty.

Table 4. Educational Unit Leadership on Use of Social Media by Business Teacher Educators $(\mathrm{N}=69)$

\begin{tabular}{lcc}
\hline \multicolumn{1}{c}{ Administrative Interest } & Yes & No \\
\hline Use of social media by department faculty is assessed each year & 10 & 59 \\
The Chair of my department/unit actively promotes its use in the classroom & 21 & 48 \\
Specific goals have been established for using social media in the classroom & 26 & 43 \\
Department policies are in place to guide teachers in its use & 27 & 42 \\
\hline
\end{tabular}

Issues identified by business teacher educators regarding uses of social media in the classroom. Respondents recorded several concerns with integrating social media into the instructional methodology when preparing future business teachers. The three major ones among business teacher educators include how to gain access to appropriate instructional apps (59.4\%); how to measure the actual impact of learning outcomes (62.3\%); and how to actually design activities that are meaningful (53.6\%). Concerns over the amount of time business faculty spend on planning and implementing social media for the classroom is a serious issue for only $33 \%$ of the sample (Table 5). 
Table 5. Issues Identified by Business Teacher Educators ( $\mathrm{N}=69)$

\begin{tabular}{|c|c|c|c|c|c|c|}
\hline & \multicolumn{2}{|c|}{ Taking Too } & \multicolumn{2}{|c|}{ Designing } & Measuring & Gaining Access \\
\hline & $\mathrm{Mu}$ & Time & Use & & Actual Impact & To Instructional \\
\hline & No & $\%$ & No. & $\%$ & No. $\%$ & No. $\%$ \\
\hline Not an Issue & 25 & 36.3 & 8 & 11.6 & $12 \quad 17.4$ & $11 \quad 15.9$ \\
\hline Moderate Issue & 21 & 30.4 & 24 & 34.8 & 20.3 & $17 \quad 24.6$ \\
\hline Serious Issue & 23 & 33.3 & $\underline{37}$ & 53.6 & $43 \quad 62.3$ & $\underline{41 \quad 59.4}$ \\
\hline Total & 69 & 100.0 & 69 & 100.0 & $69 \quad 100.0$ & 69100.0 \\
\hline
\end{tabular}

Future use of social media in the classroom.

When asked how they would like to adapt social media as part of the general instructional methodology in their department/unit, 45 or $65.2 \%$ of faculty in the sample indicated that they would like to see more integration into their instructional methodology (Table 6). However, there remains a considerable number, 19 or $27.6 \%$ that do not envision any significant change in faculty use of social media over the next 12 months from that used today.

Table 6. Foreseeable Use of Social Media in the Next 12 Months $(\mathrm{N}=69)$

\begin{tabular}{lrr}
\hline \multicolumn{1}{c}{ Direction for Social Media Integration } & No. & $\%$ \\
\hline & 45 & 65.2 \\
Like to see more integration of social media & 2 & 2.8 \\
Like to continue at same degree & 3 & 4.4 \\
Like to be used to a lesser degree & 19 & 27.6 \\
Do not foresee faculty integrating social media at all & 69 & 100.0 \\
\hline
\end{tabular}

\section{Conclusions}

Extant studies show that social media is currently only marginally implemented in business teacher education in Nigeria. Our study indicates that Nigerian business teacher educators are hesitant about its use for a number of reasons. One of these reasons is their fear of student abuse of the use of these social media. The study also shows what appears to be some hesitancy among teacher 
educators in Nigeria to integrate social media into instructional methodology. The most frequent reference to social media, and the furthermost they currently implement social media in business teacher preparatory programs, is to sensitize future teachers to alternatives they could adopt when putting together their lesson plans once employed after graduation. The other issues that appear to hinder the acceptance and more use of social media in the classroom are lack of expertise and information as to what instructional apps are readily accessible for use. Lack of infrastructure to support use of social media was not identified as an obstacle. Nonetheless, it is encouraging that a significant majority of business teacher educators would like to see the use of social media expanded. This is indicative of a willingness on the part of many business teacher educators in Nigeria to engage themselves in the process of becoming more informed as to how to use social media in the educational process.

\section{References}

Anderson, T., \& Dron, J. (2011). Three generations of distance education pedagogy. The International Review of Research in Open and Distance Learning, 12(3), 80-97. Retrieved from http $/ /$ www.irrodl.org/index.php/irrodl/article/view/890

Browning, L., Gerlich, R., Westermann, L. (2011). The new HD classroom: A hyper diverse approach to engaging with students. Journal of Instructional Pedagogies, 5,1-10.

Bryer, T. \& Zavattaro, S. (2011). Social media and public administration: Theoretical dimensions and introduction to symposium. Administrative Theory \& Praxis, 33(3), 325-340.

Cassidy, Erin, Britsch, James, Griffin, Glenda, Manolovitz, Tyler, Shen, Lisa \& Turney, Linda. (2011) Higher Education and Emerging Technologies: Student Usage, Preferences, and Lessons for Library Services. Reference \& User Services Quarterly, Vol. 50, No. 4 (Summer 2011), pp. 380-391

Chen, Baiyun, \& Bryer, Thomas (2012). Investigating instructional strategies for using social media in formal and informal learning. Retrieved online on November 2, 2016 from: http://www.irrodl.org/index.php/irrodl/article/view/1027

Cheong, PH, Park, N.\& Dutton, W. (2005). The Social Shaping of a Virtual Learning Environment: The Case of a University-wide Course Management System. Retrived on 
November 2, 2016 from: http://www.inf.ufes.br/ cvnascimento/artigos/iss ue1-art3dutton- cheong-park.pdf

Dobrzański, LA, Brytan, Z. and Brom, F. (2007) Use of e-learning in teaching fundamentals of materials science, Journal of Achievements in Materials and Manufacturing Engineering, Vol. 24, No. 2, pp.215-218.

Downes, S. (2007). An introduction to connective knowledge. Presented at the International Conference on Media, Knowledge \& Education-Exploring New Spaces, Relations and Dynamics in Digital Media Ecologies. Retrieved from http://www.downes.ca/post/33034

Ebner M., Lienhardt, C., Rohs, M. \& Meyer, I. (2010). Microblogs in higher education-a chance to facilitate informal and process-oriented learning. Computers \& Education, 55, 92-100.

Ejechi, Vikkeytour \& Nelson, Eiesuw Shola (2015). Social Media Awareness in Nigeria Education. https://www.slideshare.net/statisense/social-media-awareness-in-nigeriaeducation.

FSSE. (2010, July 25). Professors' use of technology in teaching. The Chronicle of Higher Education. Retrieved from http://chronicle.com/article/Professors-Useof/123682/?sid=wc\&utm_source=wc\&utm_medium=en

Hughes, G. (2009). Social software: New opportunities for challenging social inequalities in learning? Learning, Media and Technology, 34(4), 291-305.

Jan, H.K, \& Hermkens, K., (2011). Social media? Get serious! Understanding the functional building blocks of social media. Business Horizons (54): 241-251.

Kaplan, A. M., \& Haenlein, M. (2010). Users of the world, unite! The challenges and opportunities of Social Media. Business Horizons, 53(1), 59-68.

Liu, Y. (2010). Social media tools as a learning resource. Journal of Educational Technology Development and Exchange, 3(1), 101-114

Mazer, J.P, Murphy, R.E, \& Simonds, C.J., (2007). 'I'll See You On 'Facebook": The effects of computer mediated teacher self-disclosure on student motivation, affective learning, and classroom climate'. Communication Education, 56 (1): 1-17. 
Mazer, Joseph P., Murphy, Richard E., \& Simonds, Cheri J. (2009). The effects of teacher selfdisclosure via Facebook on teacher credibility. Learning, Media \& Technology, 34(2), 175-183.

Miller, Daniel, Costa, Elisabetta, etal., (2016). How the World Change Social Media. UCL Press,

London, England.

Mills, Nicole (2011). Situated Learning through Social Networking Communities: The Development of Joint Enterprise, Mutual Engagement, and a Shared Repertoire. CALICO Journal, Vol. 28, No. 2 (2011), pp. 345-368

Nellison. (2007, December 11). ECAR: Facebook as a teaching tool? Blog. Retrieved from http://nellison.blogspot.com/2007/12/ecar-facebook-as-teaching-tool.html

Peter, Osharive (2015) Social media and academic performance of students at the University of Lagos. (University of Lagos, Nigeria)

Sherer, Pamela \& Shea, Timonthy (2011) Using Online Video to Support Student Learning and Engagement, College Teaching, 59:2, 56-59, DOI: 10.1080/87567555.2010.511313

Siemens, G. (2004). Connectivism: A learning theory for the digital age. eLearn space. Retrieved from http://www.elearnspace.org/Articles/connectivism.htm

Siemens, G. (2005). Connectivism: Learning as network-creation. elearnspace. Retrieved from http://www.elearnspace.org/Articles/networks.htm

Solis. B. (2008). The essential guide to social media. Retrieved online on November 2, 2016, from http://www.scribd.com/doc/3283966/The-Essential-Guide-to-Social$\underline{\text { Media }}$

Suter, V., Alexander, B. \& Kaplan, P. (2005). Social software and the future of conferences right now. EDUCAUSE Review, January/February 2005, 47-59. 
Tiryakioglu, F. \& Erzurum, A. (2011). Use of social networks as an educational tool. Contemporary Educational Technology, 2(2), 135-150.

Umora, Titus Amodu (2015). Challenges and Opportunities of Utilization of Social Media by Business Education Students in Nigeria Universities. (Retrieved from: http://waset.org/publications/10003052/challenges-and-opportunities-of-utilization-ofsocial-media-by-business-education-students-in-nige ria-unive rsities 